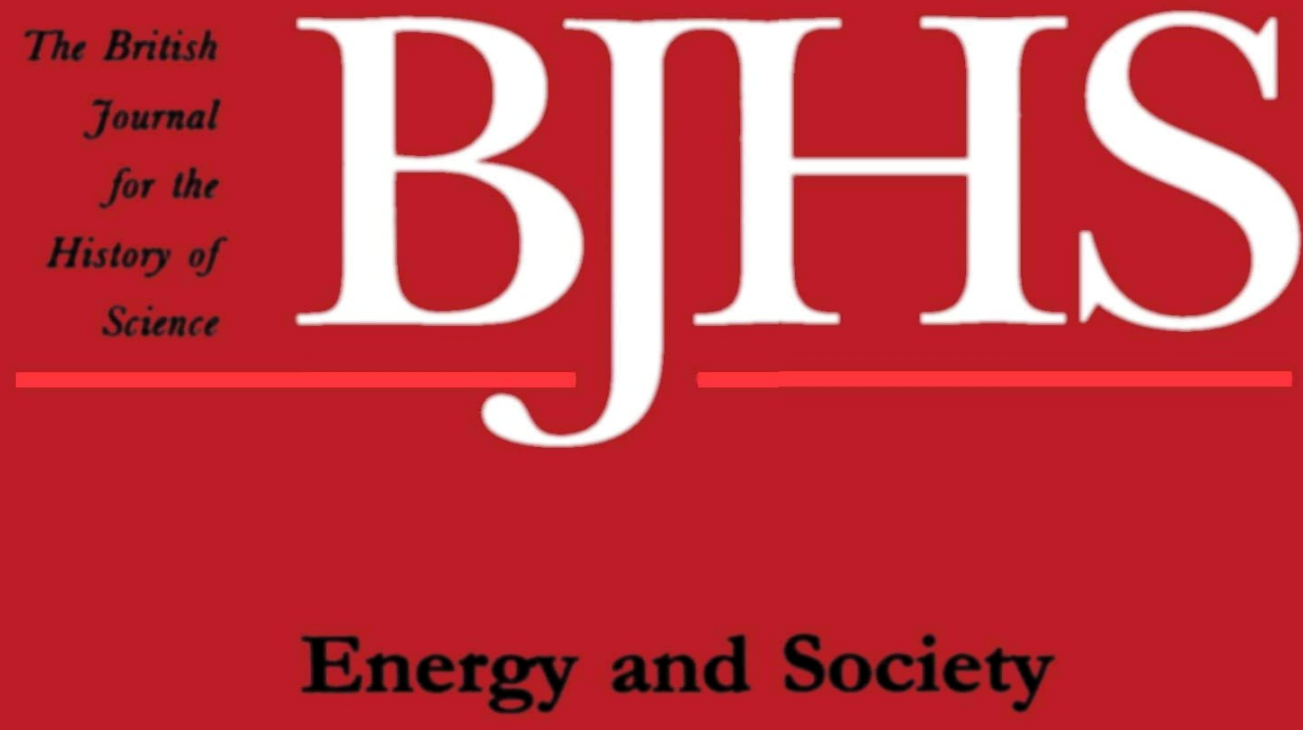

Volume 26 Pant , No. 88

ISSN Published for The British Society for the History of Science $0007-0874$ by Cambridge University Press 


$\begin{array}{ll}\begin{array}{l}\text { John Brooke Editor } \\ \text { Dept. of History }\end{array} & \begin{array}{l}\text { John Henry } \\ \text { (Book Review Editor) }\end{array} \\ \text { Furness College } & \text { Science Studies Unit } \\ \text { University of Lancaster } & \text { University of Edinburgh } \\ \text { Lancaster LA1 4YG } & \text { 21 Buccleuch Place } \\ \text { Robert Bud } & \text { Edinburgh EH8 9LN } \\ \text { Science Museum } & \text { Michael Hunter } \\ \text { South Kensington } & \text { Dept. of History } \\ \text { London SW7 2DD } & \text { Birkbeck College } \\ \text { Tore Frangsmyr } & \text { University of London } \\ \text { Office for History of Science } & \text { London WCiE 7HX } \\ \text { Uppsala University } & \text { Ludmilla Jordanova } \\ \text { Box 256, S-751 05 Uppsala } & \text { Dept. of History } \\ \text { Sweden } & \text { University of Essex } \\ \text { Owen Hannaway } & \text { Wivenhoe Park } \\ \text { Dept. of History of Science } & \text { Colchester CO4 3SQ } \\ \text { The Johns Hopkins University } & \text { David Lindberg } \\ \text { Gilman Hall } & \text { Dept. of History of Science } \\ \text { Baltimore, Maryland 21218 } & \text { Helen C. White Hall 4143 } \\ \text { USA } & \text { University of Wisconsin } \\ & \text { Madison, Wisconsin 53706 } \\ \end{array}$

\author{
Giuliano Pancaldi \\ Dept. of Philosophy \\ University of Bologna \\ Via Zamboni 38 \\ 40126 Bologna \\ Italy
}
Michael Shortland
Dept. of History and
Philosophy of Science
University of Sydney
Sydney NSW 2006
Australia

\section{Charles Webster \\ All Souls College \\ Oxford OX1 4AL}

Richard Yeo
Dept. of Humanities
Griffith University
Nathan
Brisbane
Queensland
Australia 4111

Contributions are welcome and should be sent to the Editor. They are considered on the understanding that they are unpublished and are not on offer to another journal. Two copies should be submitted, typed in double-spacing with a margin on A4 or American quarto paper. Include an abstract of 150-200 words. Quotations when long should be inset; when short, in single quotation marks. Spelling should follow the Oxford English Dictionary, and arrangement H. Hart, Rules for Compositors, Oxford, many edns. Be clear and consistent.

All papers should be rigorously documented, with references to primary and secondary sources typed separately from the text in double spacing, and numbered consecutively. Cite as follows:

I B. Smetov and D. Blogski, Chemistry in the Eighteenth Century, 2nd edn (tr. R. Roe), 5 vols., Edinburgh, 1896-1914, iii, 237-8. Only cite the publisher for good reason.

2 J. Doe, 'Searching for gravity waves', in The History of Physics (ed. A. Burn and Z. Trent), Oxford, 1982, 22-9 (subsequent references may be written: 3 Doe, op. cit. (2), 23-4).

4 N. Brown, 'Developments of the cathode ray', Joumal of Physics (1972), 7, 31-5. Abbreviated journal titles may be given where these are in common use.

Standard works such as $D N B, D S B$, may be cited thus. For theses, cite University Microfilm order number, or at least Dissertations Abstract number. Line drawings should be drawn boldly in black ink on stout white paper, feint-ruled graph paper or tracing paper. Photographs should be glossy prints of good contrast and well matched for total range. The place of an illustration should be indicated in the margin of the text and the text reference given. Each illustration must carry the name of the author and the article, its number, and a caption. Xerox copies may be sent when the article is first submitted for consideration.

(C) British Society for the History of Science. The British Society for the History of Science retains copyright for all articles published: it is the author's responsibility to secure any necessary permission for publication. Single copies of articles may be made for research or private study without further ado. Permission to make multiple copies should be obtained from the Society. Authors will receive twenty-five offprints of articles free. The Editor cannot accept responsibility for loss of a typescript, but will take every care of it; typescripts are not normally returned to authors. In all matters concerning the publication of the article, the Editor's decision is final.

Subscriptions: The British foumal for the History of Science (ISSN: 0007-0874) is published quarterly in March, June, September and December. The subscription price of Volume 26, 1993, is $£ 72$ net (USA, Canada and Mexico US \$130) post free; single parts cost $\mathcal{A}^{19}$ net (USA, Canada and Mexico US \$34) plus postage. Four parts form a volume. Orders, which must be accompanied by payment, may be sent to any bookseller, subscription agent or to the publisher: Cambridge University Press, The Edinburgh Building, Shaftesbury Road, Cambridge CB2 2RU or in the USA, Canada and Mexico to Cambridge University Press, The Journals Department, 40 West 20th Street, New York, NY 10011-4211, USA. Copies of the journal for subscribers in the USA, Canada and Mexico are sent by air to New York to arrive with minimum delay. Japanese prices for institutions (including ASP delivery) are available from Kinokuniya Company Ltd, P.O. Box 55, Chitose, Tokyo. Second-class postage paid at New York, NY and at additional mailing offices. POSTMASTER: send address changes in USA, Canada and Mexico to The British Journal for the History of Science, Cambridge University Press, 110 Midland Avenue, Port Chester NY 10573-9864. 


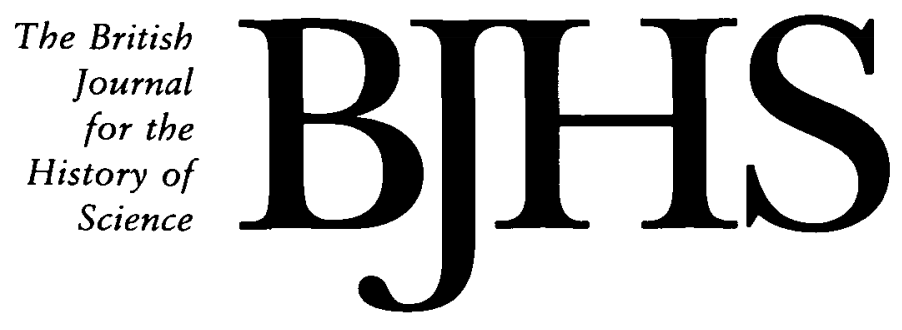

March 1993

\title{
Energy and Society
}

\author{
A special issue \\ Guest Editor: Robert Olby
}

1 Robert Olby: Introduction

5 Jonathan Winterton: The 1984-85 miners' strike and technological change

15 Ian Welsh: The NIMBY syndrome: its significance in the history of the nuclear debate in Britain

33 S. Russell: Writing energy history: explaining the neglect of CHP/DH in Britain

55 Elizabeth Sprenger and Pauline Webb: Persuading the housewife to use electricity? An interpretation of material in the Electricity Council archives

Essay review

67 David Edgerton: Tilting at paper tigers

77 Book reviews

133 Books received 